\title{
IMMUNEPOTENT CRP induces cell cycle arrest and caspase-independent regulated cell death in HeLa cells through reactive oxygen species production
}

Ana Carolina Martínez-Torres* (D), Alejandra Reyes-Ruiz, Milena Benítez-Londoño, Moises Armides Franco-Molina and Cristina Rodríguez-Padilla

\begin{abstract}
Background: Regulated cell death (RCD) is a mechanism by which the cell activates its own machinery to self-destruct. RCD is important for the maintenance of tissue homeostasis and its deregulation is involved in diseases such as cervical cancer. IMMUNEPOTENT CRP (I-CRP) is a dialyzable bovine leukocyte extract that contains transfer factors and acts as an immunomodulator, and can be cytotoxic to cancer cell lines and reduce tumor burden in vivo. Although I-CRP has shown to improve or modulate immune response in inflammation, infectious diseases and cancer, its widespread use has been limited by the absence of conclusive data on the molecular mechanism of its action.

Methods: In this study we analyzed the mechanism by which I-CRP induces cytotoxicity in HeLa cells. We assessed cell viability, cell death, cell cycle, nuclear morphology and DNA integrity, caspase dependence and activity, mitochondrial membrane potential, and reactive oxygen species production.

Results: I-CRP diminishes cell viability in HeLa cells through a RCD pathway and induces cell cycle arrest in the G2/M phase. We show that the I-CRP induces caspase activation but cell death induction is independent of caspases, as observed by the use of a pan-caspase inhibitor, which blocked caspase activity but not cell death. Moreover, we show that I-CRP induces DNA alterations, loss of mitochondrial membrane potential, and production of reactive-oxygen species. Finally, pretreatment with $\mathrm{N}$-acetyl-L-cysteine (NAC), a ROS scavenger, prevented both ROS generation and cell death induced by I-CRP.

Conclusions: Our data indicate that I-CRP treatment induced cell cycle arrest in G2/M phase, mitochondrial damage, and ROS-mediated caspase-independent cell death in HeLa cells. This work opens the way to the elucidation of a more detailed cell death pathway that could potentially work in conjunction with caspase-dependent cell death induced by classical chemotherapies.
\end{abstract}

Keywords: I-CRP, Bovine dyalisable leukocyte extract, bDLE, Cell death, Cervical cancer, Immunotherapy, Transfer factor, Immunomodulator, Apoptosis

\footnotetext{
* Correspondence: ana.martinezto@uanl.edu.mx

Universidad Autónoma de Nuevo León, Facultad de Ciencias Biológicas,

Laboratorio de Inmunología y Virología, 66455 Monterrey, Mexico
} 


\section{Background}

Regulated cell death (RCD) is a physiological mechanism by which the cell activates its own machinery to self-destruct. It is important for the maintenance of tissue homeostasis and its deregulation induces diseases such as cancer. Among the different types of cancer, cervical cancer remains one of the leading causes of women death worldwide [1]. Although several approaches such as immune therapy with cytokines, polyamine synthesis inhibitors, individual micronutrient supplementation and pharmaceutical agents exist, they have shown a limited success [2, 3]. And while chemotherapy and radiotherapy are front-line treatments against this and other types of cancer, they cause important side effects. These are reasons why the development of new therapies to improve existing treatments is a major challenge. Naturalderived products have recently attained a lot of interest for their ability to modulate the signaling pathways involved in cancer proliferation or for their protective potential in radiotherapy and chemotherapy [4]. Some such natural-derived products are dialyzable leukocyte extracts (DLE), which are mixtures of low molecular weight substances $(<12 \mathrm{kDa})$ released from disintegrated leukocytes of human, bovine, or other species' blood or tissue [5, 6]. DLEs have been used as therapeutic agents in the treatment of a broad spectrum of diseases, usually related with the immune system [7], including cancer, where they have shown to improve the quality of patients' lives $[8,9]$.

Results obtained in our laboratory show that a type of bovine DLE obtained from disintegrated spleen, IMMUNEPOTENT CRPC (I-CRP), is cytotoxic to several cancer cell lines [6]. In the MCF-7 cell line, I-CRP inhibited cell growth, suppressed the DNA-binding activity of AP-1, decreased c-Jun protein expression [8] and modulated the mRNA expression of NFATx, NFATc, NFkB, c-Jun, c-Fos, p53, bag-1, c-myc, bax, bcl-2 [6]. It has also prevented murine melanoma cell growth and diminished VEGF release [10]. However, the mechanisms by which I-CRP exerts these effects and the type of cell death activated in these or other cell lines are still unknown. The limited information of its molecular action mechanisms has limited its widespread use.

The purpose of this study was to analyze the molecular pathways by which I-CRP exerts its cytotoxicity. We used the cervical cancer-derived HeLa cell line to further characterize its mechanism of cytotoxicity. We found that I-CRP induces caspase-independent but ROS-dependent cell death, loss of mitochondrial membrane potential, DNA fragmentation and condensation, and cell cycle arrest in HeLa cells.

\section{Methods}

\section{Cell culture}

Human cervix adenocarcinoma HeLa (ATCC CCL- $^{\oplus \text { is }}$ ) and human cervix squamous carcinoma $\mathrm{SiHa}\left(\mathrm{ATCC}^{\bullet}\right.$
HTB- $35^{\mathrm{TM}}$ ) cells were obtained from the American Type Culture Collection and maintained in a humidified incubator containing $5 \% \mathrm{CO}_{2}$ at $37{ }^{\circ} \mathrm{C}$. HeLa cells were cultured in DMEM-F12 supplemented with 10\% fetal bovine serum (FBS) and 1\% penicillin-streptomycin (GIBCO). Cells were routinely grown in plastic tissue-culture dishes (CORNING).

\section{Cell death induction and inhibition}

The bovine dialyzable leukocyte extract, IMMUNEPOTENT CRPC (I-CRP), was produced as described previously $[6,11]$, and was dissolved in media. One unit of I-CRP is defined as the product obtained from $1 \times 10^{8}$ leukocytes [11, 12]. Etoposide and QVD.opH (BioVision) were dissolved in DMSO. N-acetyl-L-cysteine (NAC) and $\mathrm{H}_{2} \mathrm{O}_{2}$ were dissolved in water. For cell death induction, cells were seeded and incubated with the indicated concentration of I-CRP, etoposide, or $\mathrm{H}_{2} \mathrm{O}_{2}$ at the indicated times. For cell death inhibition, QVD.oph or NAC were added 30 min before I-CRP, etoposide, or $\mathrm{H}_{2} \mathrm{O}_{2}$ treatment. All stock solutions were wrapped in foil and stored at $-20{ }^{\circ} \mathrm{C}$. All reagents were from SIGMAALDRICH, unless otherwise stated.

\section{Cell viability assessment}

Cell growth inhibition was determined by measuring 3(4,5-dimethylthiazol-2-yl)-2,5-diphenyltetrazolium bromide (MTT) dye absorbance by living cells, as previously described [6]. In brief, $5 \times 10^{3}$ cells per well were seeded in 96-well microtiter plates for MTT assays. After exposure to IMMUNEPOTENT CRP for 4, 8, 16, 24, 48, and $72 \mathrm{~h}$, twenty microliters of MTT solution $(2 \mathrm{mg} / \mathrm{ml}$ in PBS) were added to each well. The plates were incubated for 3 additional hours at $37{ }^{\circ} \mathrm{C}$, after which the MTT solution in the medium was aspirated and $200 \mu \mathrm{l}$ of DMSO were added to each well to solubilize the formazan crystals formed in the viable cells. The optical density was measured at $570 \mathrm{~nm}$ using a microplate reader (Synergy2, Biotek).

\section{Cell death analysis}

Cell death was determined by staining cells with annexin-V-allycophalloidin (APC, BD) and propidium iodide (PI), as previously described [13]. In brief, $2 \times 10^{5}$ cells were seeded in 24-well plates (Corning) and were incubated with IMMUNEPOTENT CRP for $24 \mathrm{~h}$, with or without incubation with QVD.oph. Cells were then detached and washed twice with PBS and then resuspended in $200 \mu \mathrm{l}$ of binding buffer (10 mM HEPES/ $\mathrm{NaOH}$ pH 7.4, $140 \mathrm{mM} \mathrm{NaCl}, 2.5 \mathrm{mM} \mathrm{CaCl}$ ). Cells were then stained and subsequently assessed with a flow cytometer (Becton Dickinson, BDAccury6) and analyzed using FlowJo Software. 


\section{Cell counting and blue trypan staining}

Time-lapse cellular cytotoxicity induced by $1.25 \mathrm{U} / \mathrm{mL}$ of I-CRP treatment was measured with trypan blue exclusion assay. Briefly, $1 \times 10^{4}$ cells were seeded into 96-well plates and treated with I-CRP for $16,24,48$, and $72 \mathrm{~h}$, or left without treatment, as a control. After the incubation period, the cells were harvested and washed twice with PBS, and the cell pellet was then resuspended with $0.5 \mathrm{~mL}$ PBS. Then, $20 \mu \mathrm{L}$ of suspension was mixed with equal volume of $0.4 \%$ trypan blue and was count using a Neubauer chamber (Superior Marienfeld) and a clear-field microscopy (Primostar Zeiss). Each I-CRP and control was assayed three times in quintuplicate. Total cells were counted, and the percentage of trypan blue positive cells was obtained.

\section{Cell morphology assessment}

HeLa cells were cultured in 24-well plates and left untreated or incubated for 16, 24, 48, and $72 \mathrm{~h}$ with I-CRP. After the incubation time, plates were observed in an inverted microscope (NIKON TS100) and pictures were obtained with an Infinity1 (Lumenera) camera.

\section{Cell cycle analysis}

Cell cycle distributions were determined by PI staining. In brief, $5 \times 10^{5}$ cells in 6-well dishes (CORNING) were incubated with I-CRP at different times $(4,8,16,24,48 \mathrm{~h})$ and concentrations $(1,1.25$, and $2 \mathrm{U} / \mathrm{mL})$. Cells were then washed with PBS and fixed in $70 \%$ ethanol. Cells were washed again with PBS, then incubated with PI $(10 \mu \mathrm{g} / \mathrm{ml})$ with simultaneous RNase treatment at $37^{\circ} \mathrm{C}$ for $30 \mathrm{~min}$. Cell DNA contents were measured using a flow cytometer (Becton Dickinson, BDAccury6), and analyzed using FlowJo Software.

\section{Nuclear assessment}

For DNA degradation we analyzed the SubG1 population obtained from cell cycle analysis, using a flow cytometer (Becton Dickinson, BDAccury6), and analyzed using FlowJo Software. For chromatin condensation we did Hoechst staining. In brief $10 \times 10^{5}$ cells were incubated in 6-well plates, then treated with I-CRP and then were washed in PBS and fixed with paraformaldehyde $4 \%$. We stained the cells for 5 min using $5 \mu \mathrm{g} / \mathrm{ml}$ Hoechst 33,342 (SIGMA-ALDRICH). Cells were then washed with PBS, observed using a fluorescence microscope (OLYMPUS IX70) and analyzed with Image-J software.

\section{Caspase analysis}

Caspase activity was measured using Caspase 3 (active) FITC staining kit (ABCAM). In brief, $5 \times 10^{5}$ cells in 6-well dishes (CORNING) were incubated with IMMUNEPOTENT CRP alone or co-cultured with QVD.oph. Cells were then recuperated and stained following the manufacturer's instructions. Caspase activity was measured using a flow cytometer (Becton Dickinson, BDAccury6) and analyzed using FlowJo Software.

\section{Mitochondrial membrane potential analysis}

Mitochondrial membrane potential was measured using TMRE (125 nM) (SIGMA-ALDRICH). In brief, $5 \times 10^{5}$ cells in 6-well dishes (CORNING) were incubated as indicated. Cells were then recuperated, washed with PBS, stained, incubated at $37{ }^{\circ} \mathrm{C}$ for $30 \mathrm{~min}$, and measured using a flow cytometer (Becton Dickinson, BDAccury6) and analyzed using FlowJo Software. For fluorescence microscopy, cells were washed in PBS after treatment, stained, and incubated at $37{ }^{\circ} \mathrm{C}$ for $30 \mathrm{~min}$. Cells were then washed with PBS and observed using a fluorescence microscope (OLYMPUS IX70).

\section{ROS production analysis}

ROS generation was measured using DCFDA $(2.5 \mu \mathrm{M})$ (Invitrogen). In brief, $5 \times 10^{5}$ cells in 6-well dishes (CORNING) were incubated as indicated. Cells were then recuperated, washed with $\mathrm{PBS}$, stained, incubated at $37^{\circ} \mathrm{C}$ for $30 \mathrm{~min}$, and measured using a flow cytometer (Becton Dickinson, BDAccury6) and analyzed using FlowJo Software. For fluorescence microscopy cells were washed in PBS after treatment, stained, and incubated at $37{ }^{\circ} \mathrm{C}$ for 30 min. Cells were then washed with PBS and observed using a fluorescence microscope (OLYMPUS IX70).

\section{Statistical analysis}

The results given in this study represent the mean of at least four independent experiments done in triplicate (mean $\pm \mathrm{SD}$ ). The data was analyzed using GraphPad Prism (San Diego, CA, USA). Statistical analysis was done using paired student T-test. The statistical significance was defined as $p<0.05$.

\section{Results \\ IMMUNEPOTENT CRP-treatment diminishes cell viability in HeLa cells \\ I-CRP has been shown to suppress cell viability in several tumor cell lines $[6,10]$. However, its effect on cervical cancer-derived HeLa cell line, has not been assessed, thus, we determined the effect of I-CRP on these cells. IMMU- NEPOTENT CRP decreased the viability of HeLa cells in a dose- and time-dependent-manner (Fig. 1). We observed low cytotoxic effects after $4 \mathrm{~h}$ and $8 \mathrm{~h}$ of treatment, and observed that after $16 \mathrm{~h}$ we could detect a considerable diminution of cell viability, which continued to decrease after 24, 48, and $72 \mathrm{~h}$. The cytotoxic concentration that decreased the viability of $50 \%$ of the cells (CC50) after $8 \mathrm{~h}$ is $2 \mathrm{U} / \mathrm{mL}$, after $16 \mathrm{~h}$ and $24 \mathrm{~h}$ of treatment is $1 \mathrm{U} / \mathrm{mL}$, after $48 \mathrm{~h}$ is $0.75 \mathrm{U} / \mathrm{mL}$, and after a $72 \mathrm{~h}$-treatment it is $0.5 \mathrm{U} / \mathrm{mL}$ (Fig. 1).}




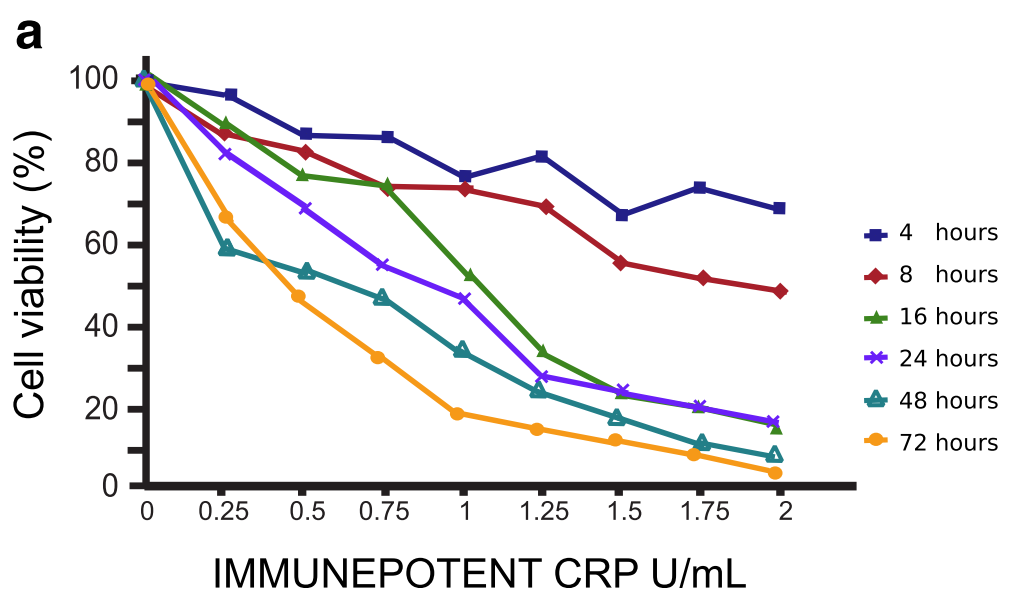

Fig. 1 Concentration and time effect of I-CRP exposure on HeLa cell viability. After HeLa cells were treated with various concentrations $(0.25,0.5$, $0.75,1.0,1.25,1.5,1.75,2 \mathrm{U} / \mathrm{mL})$ of I-CRP for different times $(4,8,16,24,48,72 \mathrm{~h})$, cell viability was measured by MTT assay. The percentages refer to relative cell viability represented as percentage of control (non-treated cell viability $=100 \%$ )

\section{IMMUNEPOTENT CRP induces cell death and inhibits cell recovery in HeLa cells}

As the MTT assay measures cell metabolism through the capacity of the viable cells to reduce MTT into formazan crystals [14], we further evaluated cell death by assessing phosphatidylserine (PS) exposure (Annexin-V-APC) and membrane permability (propidium iodide, PI) at different doses of I-CRP after $24 \mathrm{~h}$ of treatment (Fig. 2). In healthy cells, PS is generally restricted to the inner leaflet of the cell membrane, and the exposure of phosphatidylserine on the outer leaflet is an effect that is commonly observed during apoptosis [15]. We determined PS externalization by flow cytometry of Annexin V-APC/Propidium Iodide-labelled cells that were treated with IMMUNEPOTENT CRP at different doses for $24 \mathrm{~h}$. As shown in Fig. 2, I-CRP induced a slight population of AnnexinV-positive and PI-negative cells and most of them were double positive cells. Furthermore, as expected with MTT results, I-CRP induced celldeath in a concentration-dependent manner. It provoked a slight cell death induction at $0.75 \mathrm{U} / \mathrm{mL}$, reaching $35 \%$ at $1 \mathrm{U} / \mathrm{mL}$. At a $1.25 \mathrm{U} / \mathrm{mL}$ dose it induced cell death in $50 \%$ of the cells, increasing near to $80 \%$ at a $1.5 \mathrm{U} / \mathrm{mL}$ dose, and reaching complete cell death at $2 \mathrm{U} / \mathrm{mL}$. Additionally, when we assessed trypan blue exclusion using $1.25 \mathrm{U} / \mathrm{mL}$ after a

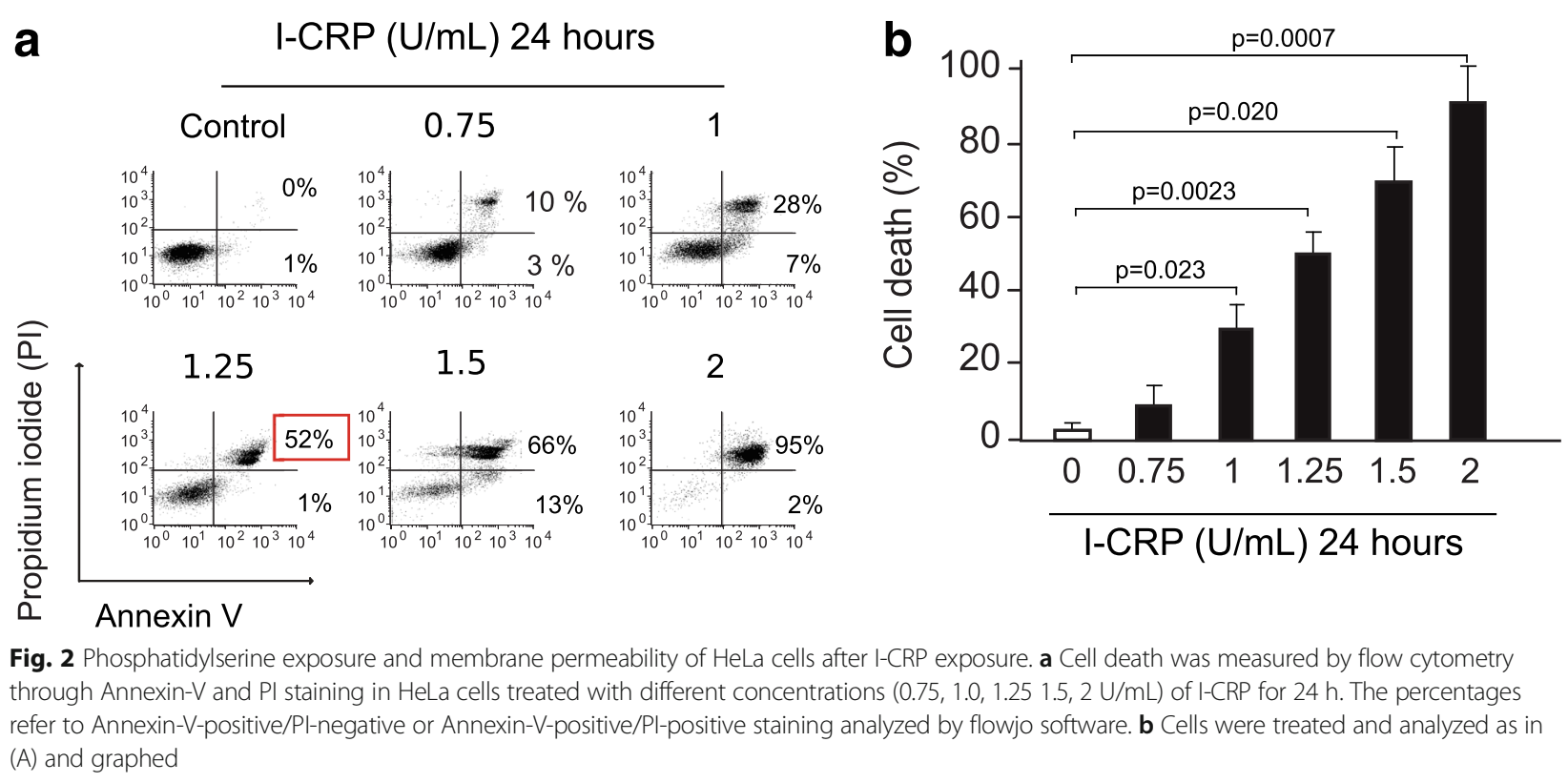


treatment of $16 \mathrm{~h}, 24 \mathrm{~h}, 48 \mathrm{~h}$, and $72 \mathrm{~h}$, we saw that it occurs at a time-dependent manner, reaching complete cell death after $48 \mathrm{~h}$ of treatment (Fig. 3a).

Next, we assessed cell recovery after different times of $1.25 \mathrm{U} / \mathrm{mL}$ treatment with I-CRP and then treatmentwithdrawal. The cells were treated for 16 h, 24 h, 48 h, or $72 \mathrm{~h}$, then washed and reseeded for $24 \mathrm{~h}$. We observed that the cells were already compromised, as they did not recover from the MTT reduction, maintaining the same relative viability as if the treatment had not been removed (Fig. 3b, 1). Moreover, morphological assessment showed a reduction of cell confluence and alterations in cell morphology that were visible after $16 \mathrm{~h}$ of treatment and these alterations increased through time, reaching a complete cell loss after $72 \mathrm{~h}$ of I-CRP- treatment (Fig. 3C).
IMMUNEPOTENT CRP induces cell cycle arrest in HeLa cells Interestingly, although MTT showed that the CC50 after 24-h treatment was $1 \mathrm{U} / \mathrm{mL}$, we confirmed that it is necessary to use $1.25 \mathrm{U} / \mathrm{mL}$ of I-CRP to induce cell death. Because the decrease in MTT activity can be due to cell death and/or to the decrease of cell division, we further assessed cell cycle after I-CRP treatment, to determine if it induces cell cycle arrest. A seen in Fig. 4, I-CRP effectively induces cell cycle arrest in G2/M phase at $1 \mathrm{U} / \mathrm{mL}$, which also increases at a concentration of $1.25 \mathrm{U} / \mathrm{mL}$. We could not detect cell cycle arrest, at a concentration of $2 \mathrm{U} / \mathrm{mL}$ probably because cell death was directly induced at this concentration, as shown in Fig. 2a.

To verify that cell cycle arrest was time-dependent, we used $1.25 \mathrm{U} / \mathrm{mL}$ treatment and assessed cell cycle arrest after $4,8,16,24$, and $48 \mathrm{~h}$ of treatment. At $4 \mathrm{~h}$ of treatment

\section{a}

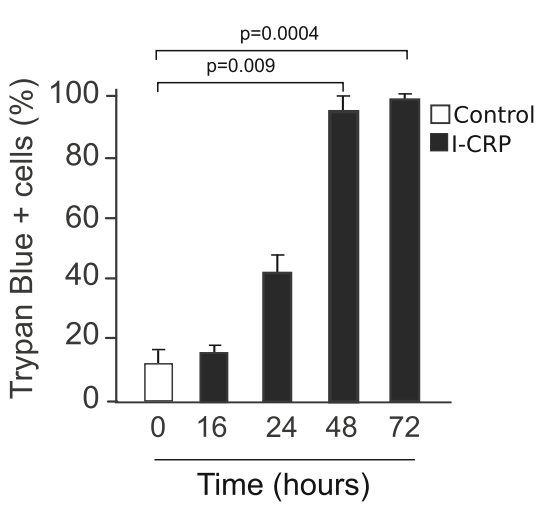

C

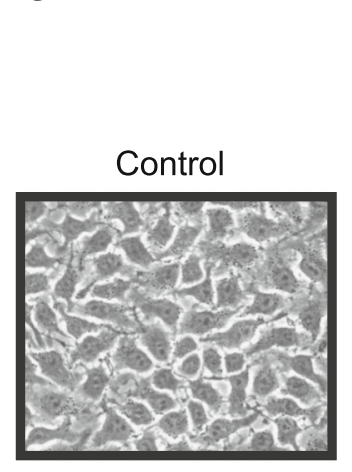

I-CRP 16h

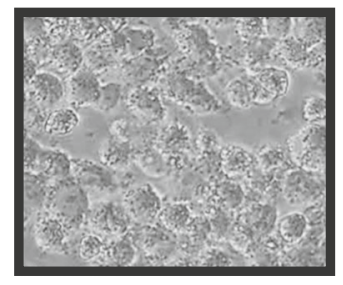

I-CRP 48h

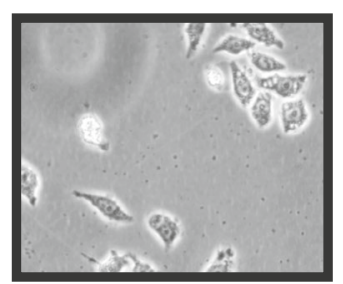

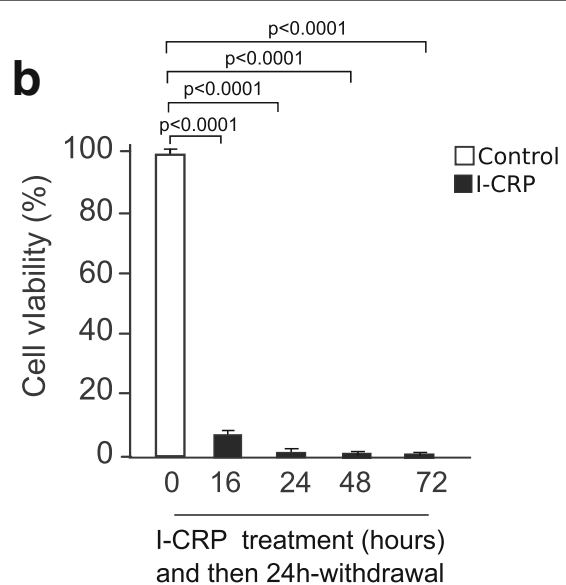

and then 24 h-withdrawal

I-CRP 24h

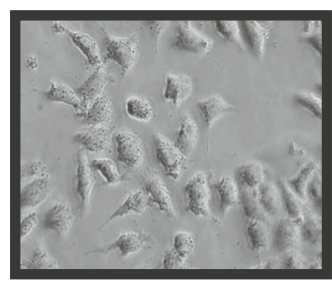

I-CRP $72 h$

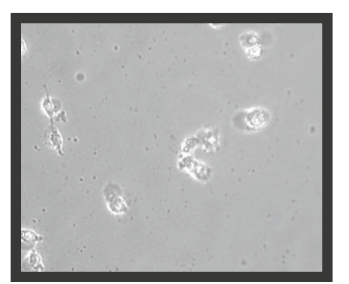

Fig. 3 Time-dependent characteristics of cell death induced by I-CRP in HeLa cells. a Cell death was measured by trypan blue exclusion after I-CRP treatment $(1.25 \mathrm{U} / \mathrm{mL})$ for $16 \mathrm{~h}, 24 \mathrm{~h}, 48 \mathrm{~h}$, and $72 \mathrm{~h}$ and was analyzed as a percentage of living cells and graphed. $\mathbf{b}$ Effect on cell viability after withdrawal of I-CRP $(1.25 \mathrm{U} / \mathrm{mL})$ administered for $16 \mathrm{~h}, 24 \mathrm{~h}, 48 \mathrm{~h}$ and $72 \mathrm{~h}$, was measured by MTT assay after $24 \mathrm{~h}$ of withdrawal. The percentages refer to relative cell viability represented as \% control (non-treated cell viability $=100 \%)$. c Changes in morphology of HeLa cells induced by treatment with I-CRP $(1.25 \mathrm{U} / \mathrm{mL})$ for $16 \mathrm{~h}$, $24 \mathrm{~h}, 48 \mathrm{~h}$ and $72 \mathrm{~h}$, observed in an inverted microscope (NIKON TS100) (20X) 


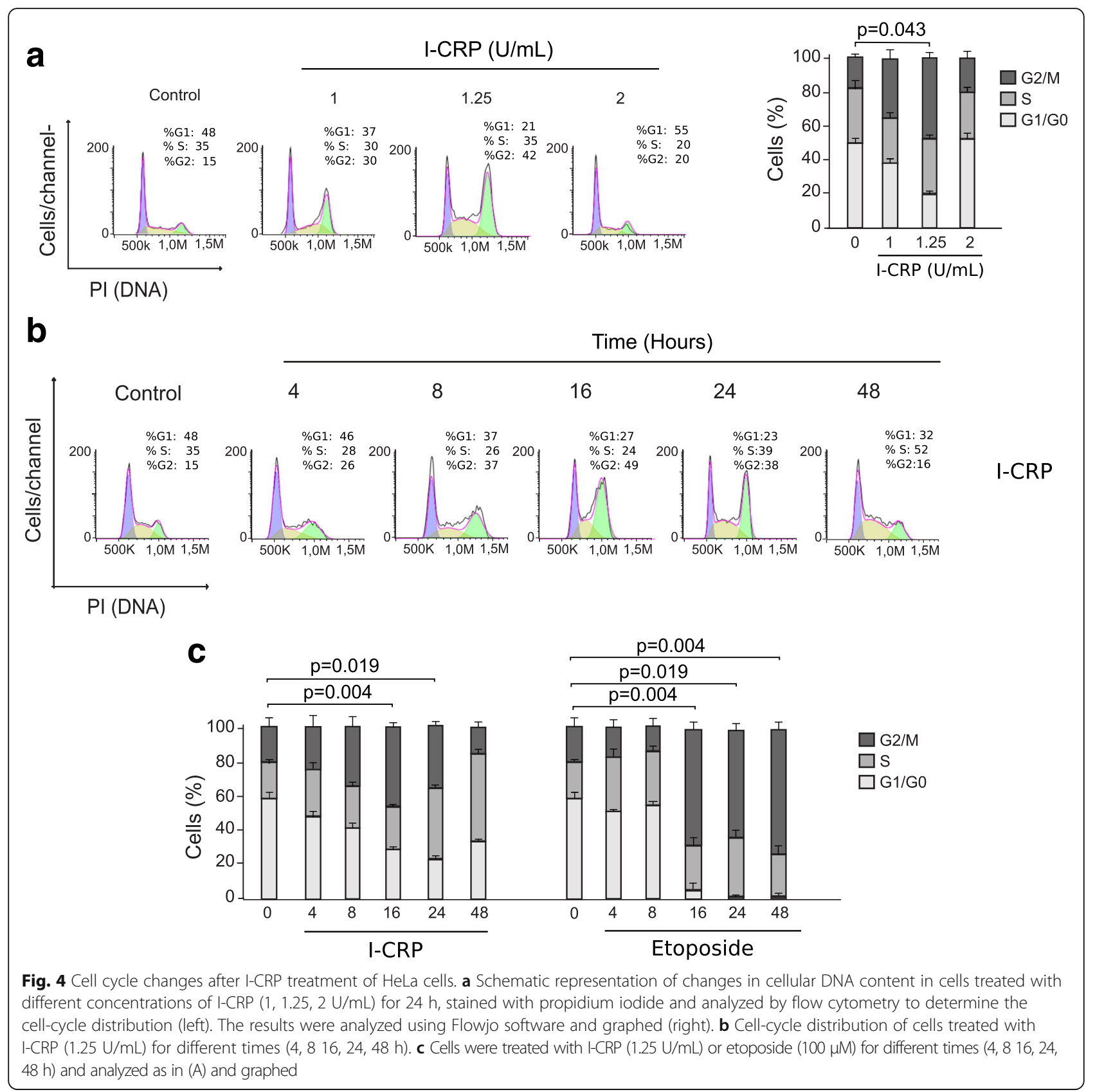

we noticed a slight accumulation of cells in G2/M phases that increased with time and reached the maximum accumulation after $24 \mathrm{~h}$ of treatment, then decreased after $48 \mathrm{~h}$ (Fig. 4b, c). We used Etoposide as a positive control, as it is a topoisomerase II inhibitor that induces p53-dependent cell cycle arrest in G2/M phase [16], and we saw a more potent cycle arrest in G2/ $\mathrm{M}$ phase at 16, 24, and $48 \mathrm{~h}$ of treatment (Fig. 4c). Although both treatments induce cell cycle arrest in G2/ $M$ phase, I-CRP induces this arrest earlier and it probably does it in a different manner.

\section{IMMUNEPOTENT CRP induces DNA alterations}

One of the major features of regulated cell death is the degradation of DNA and nuclear condensation. Different types of endonucleases activated during many types of RCD cleave sections of internucleosomal DNA and cause extensive DNA fragmentation [17]. The fragmented, low molecular weight DNA can be extracted from the cells during the process of cell staining, and cells with fractional, sub-G1, DNA content can be quantified. To assess DNA degradation, we quantified sub-G1 population of cells treated at different times with I-CRP. 
As shown in Fig. 5a, Sub-G1 was detected after $48 \mathrm{~h}$ of I-CRP treatment, indicating the late stages of cell death, similar to the effect observed by Etoposide treatment. To further characterize these nuclear alterations, we stained HeLa cells with Hoechst and nuclear morphology was assessed using a fluorescence microscope. As shown in Fig. 5b, I-CRP-treated cells show an altered nucleus after $16 \mathrm{~h}$ of treatment, and a type- 2 necklace condensation [18], after 48 h, while Etoposide treatment shows a higher DNA condensation (Fig. c). Altogether, these results demonstrate that I-CRP induces DNA degradation and a partial chromatin condensation, indicating that nuclear alterations are a late step in I-CRP induced cell death.

\section{IMMUNEPOTENT CRP induces caspase-independent cell death}

To verify the main molecular regulators of this type of cell death, we assessed caspase activity. As shown in Fig. 6, I-CRP induces slight caspase activation, as determined by the detection of caspase- 3 activation (A). To determine if this type of cell death was dependent on caspase activity we used the pan-caspase inhibitor QVD.oph [19] and we found that, contrary to etoposide treatment, I-CRPmediated cell death was independent of caspase-activation
(Fig. 6b), in fact, the use of this pan-caspase inhibitor blocked caspase activation and etoposide-induced apoptosis but it did not inhibit the cell death induced by I-CRP (Fig. 6b). This result shows that although a small percentage of caspase- 3 is activated by I-CRP, caspase-activity is not necessary for I-CRP-induced RCD.

\section{IMMUNEPOTENT CRP induces loss of mitochondrial} membrane potential and ROS-dependent cell death

The role of mitochondria in cell death is widely accepted, as they play a central role in cellular energetics and cell death signaling [20]. Moreover, mitochondrial dysfunction leads to reactive-oxygen species (ROS) generation [21-23], which has been associated with caspase-independent types of cell death [24]. As we found that caspases are dispensable for this type of cell death, we assessed whether the ICRP was able to induce loss of mitochondrial membrane potential and ROS production, through tetramethylrhodamine ethyl ester (TMRE) and $2^{\prime}, 7^{\prime}$-dichlorofluorescin diacetate (DCFDA) staining, followed by fluorescence microscopy and flow cytometric analysis. As shown in Fig. 7, I-CRP induces loss of mitochondrial membrane potential and ROS production, as shown by fluorescence microscopy $(7 \mathrm{~A}, \mathrm{C})$ and flow cytometry $(7 \mathrm{~B}, \mathrm{D})$, in HeLa cells.

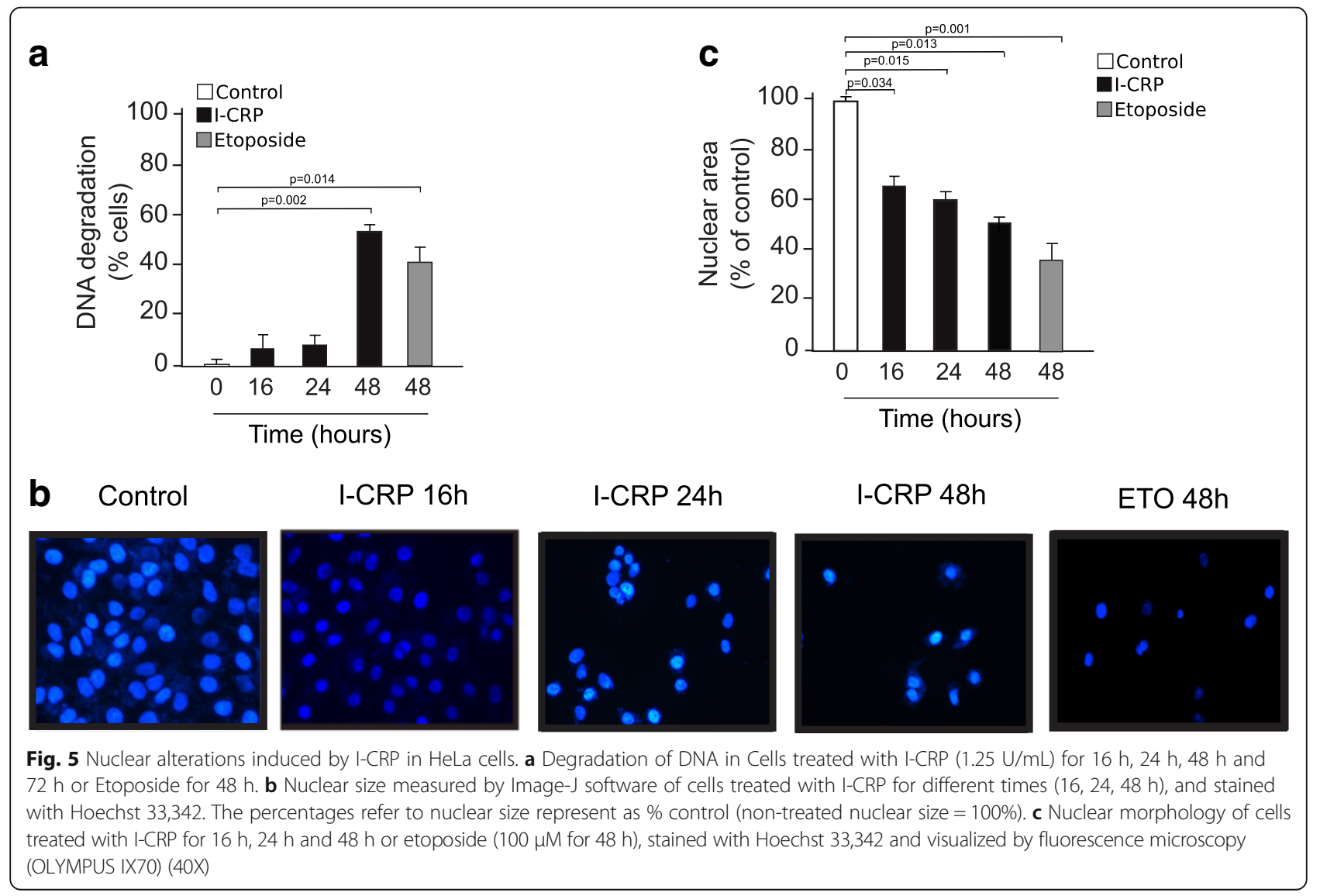




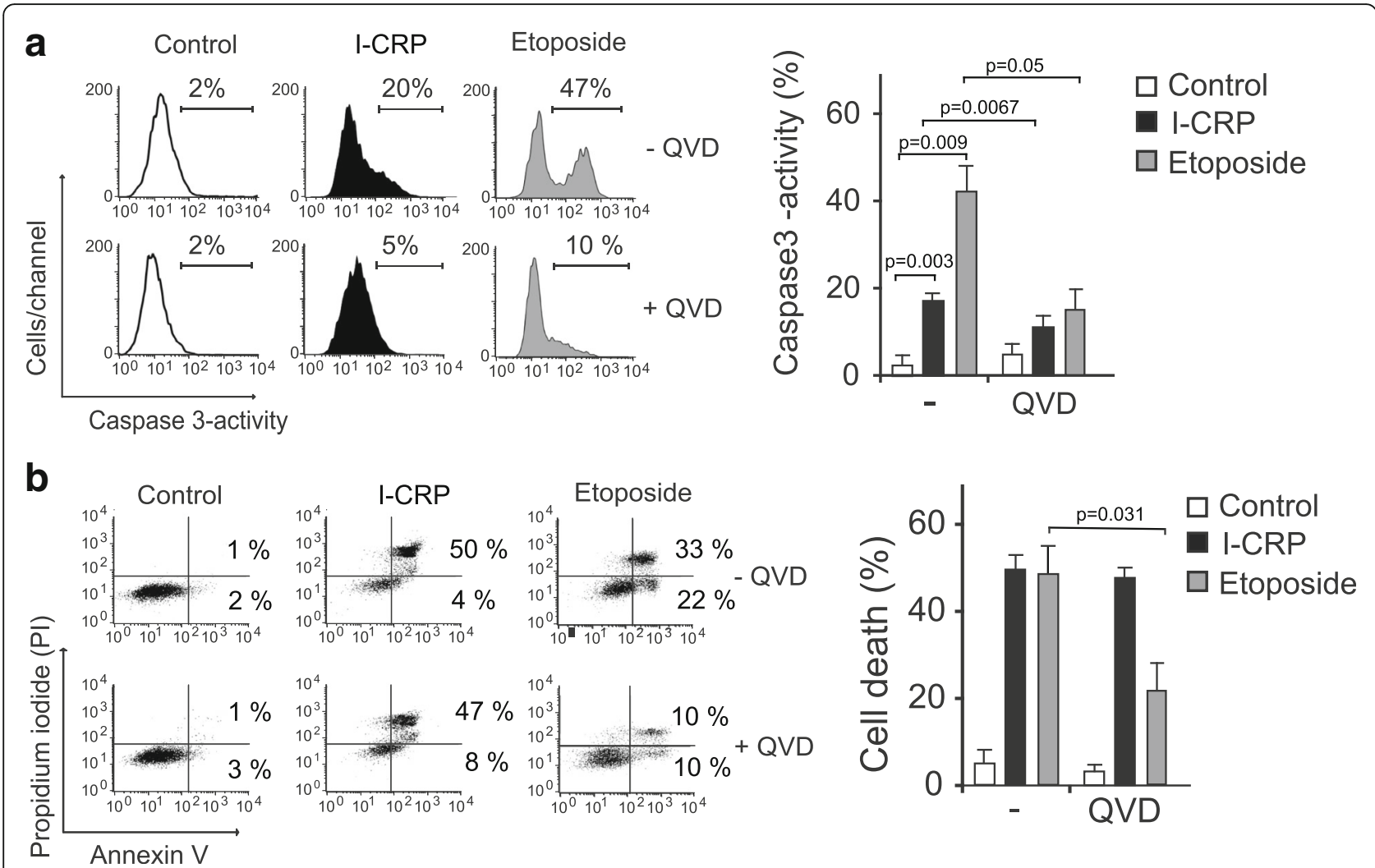

Fig. 6 Caspase-3 activity and effects of pan-caspase inhibition on HeLa cells treated with I-CRP. a Caspase-3 activation was measured by flow cytometry in cells that were left alone or pretreated with QVD.oph and then treated with I-CRP (1.25 U/ml) or etoposide (100 $\mu$ M) for 24 h, data was then analyzed and graphed. b Cell viability was determined by flow cytometry in cells that were left alone or pretreated with QVD.oph and then treated with I-CRP (1.25 U/ml) or etoposide $(100 \mu \mathrm{M})$ for $24 \mathrm{~h}$. The percentages refer to Annexin-V-positive or Annexin-V-positive/PI-positive staining

Moreover, I-CRP- treatment induces ROS production in a level similar to Etoposide and $\mathrm{H}_{2} \mathrm{O}_{2}$ at their $\mathrm{CC} 50$ (8A). We also found a correlation between ROS production and PS exposure, because approximately $50 \%$ of the cells display these two features (Fig. 8). Moreover, when we use QVD we can see that it is not able to inhibit ROS production in I-CRP treated cells, while it inhibits its production in Etoposide-treated cells and partially in $\mathrm{H}_{2} \mathrm{O}_{2}$-treated cells (Fig. 8a). Then, we used the antioxidant $\mathrm{N}$-acetyl-L-cysteine (NAC), which increases intracellular GSH levels and possesses thiol-disulfide exchange activity $[25,26]$, to determine if it was able to inhibit ROS production. As shown in Fig. 8a, NAC was able to inhibit ROS production induced by I-CRP, Etoposide, and $\mathrm{H}_{2} \mathrm{O}_{2}$.

Finally, to determine if ROS were playing a role in I-CRPinduced cell death, we pretreated cells with NAC, before treating them with I-CRP. As shown in Fig. 8b, NAC was able to inhibit I-CRP induced cell death in HeLa and $\mathrm{SiHa}$ (Additional file 1: Fig. S1) cells, as observed by the reduction of Annexin $\mathrm{V}+$ staining. The same result was observed when assessing $\mathrm{H}_{2} \mathrm{O}_{2}$-treated cells previously incubated with NAC and partially in Etoposide-treated cells (Fig. 8b).
NAC also inhibited caspase-3 activation in I-CRPtreated cells (Additional file 2: Fig. S2), which indicated that caspase- 3 activation is a secondary effect of ROS production after I-CRP treatment.

Overall these results show that I-CRP induces a regulated type of cell death that is independent of caspase-3 activation, and induces cell cycle arrest, DNA fragmentation, mitochondrial damage, and ROS-dependent cell death.

\section{Discussion}

Conventional therapies used against cancer, including cervical cancer [27, 28], exhibit many side effects due to their lack of specificity to cancer cells, while recently developed approaches have shown a limited success [29-31]. Because of this, the search for new therapies that improve existing treatments has become an important subject of study.

Dialyzable leukocyte extracts containing transfer factors have been used as adjuvants for chemotherapy for osteosarcoma [32], prostate cancer [33], lung cancer [34, 35], and breast cancer [9]. In these cases the extract has proven to be beneficial for cancer patients by improving their immune system by increasing cell-mediated cytotoxicity [32] or leukocyte cell number $[9,35]$, resulting in higher survival 


\section{a}

Control

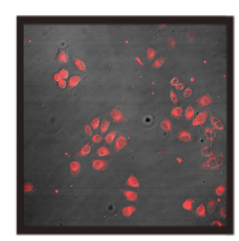

I-CRP 24h

C

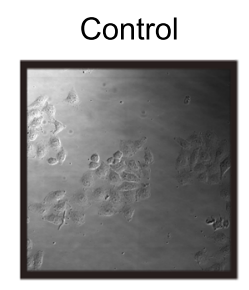

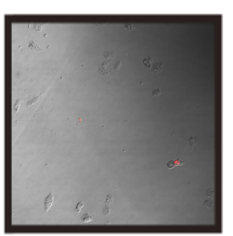

TMRE I-CRP 24h

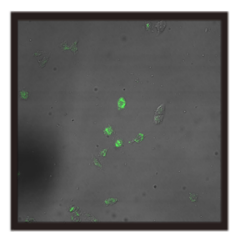

b

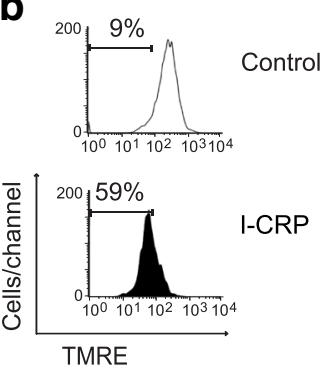

d

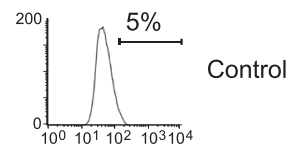

DCFDA

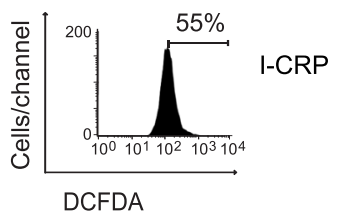

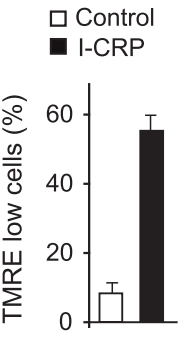

$\square$ Control

$$
\text { I-CRP }
$$

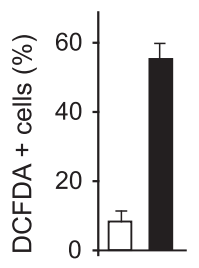

Fig. 7 Mitochondrial membrane potential and ROS production of HeLa cells treated with I-CRP. a Mitochondrial membrane potential was measured by fluorescence microscopy $(25 X)$ using TMRE staining in non-treated cells (control) or treated with I-CRP (1.25 U/mL). b Mitochondrial membrane potential was measured by flow cytometry through TMRE staining in cells left alone or treated with I-CRP $(1.25 \mathrm{U} / \mathrm{mL})$ for 24 h. c ROS levels were measured by fluorescence microscopy (25X) using DCFDA staining in non-treated cells (control) or treated with I-CRP $(1.25 \mathrm{U} / \mathrm{mL})$. d ROS levels were measured by flow cytometry through DCFDA staining in cells left alone or treated with I-CRP $(1.25 \mathrm{U} / \mathrm{mL})$ for $24 \mathrm{~h}$

rates in patients treated [12]. Furthermore, it has also been demonstrated that dialyzable leukocyte extracts alone can be cytotoxic to cancer cells [5, 36-39], which has been specially studied using the bovine dialyzable leukocyte extract, IMMUNEPOTENT-CRP $[6,8,10]$. However, the mechanism underlying cell viability reduction by dialyzable leukocyte extracts, including I-CRP is misunderstood. Although several studies were done to understand this mechanism, no principal effector has been found.

In the present study, we showed that I-CRP reduced cell viability of HeLa cells by inducing cell cycle arrest and cell death. I-CRP induced changes in cell morphology, and decreased cell viability in a time and concentration-dependent manner, and we realized that this decrease was due to both cell death and cell cycle arrest. Cell cycle was arrested in phase $\mathrm{G} 2 / \mathrm{M}$ and reached its maximum at $1.25 \mathrm{U} / \mathrm{mL}$, and after 16 and 24-h of treatment. We also observed a low caspase- 3 activity generated by I-CRP, however this activity is not necessary for the execution of cell death, because cell death occurred even after the activation of caspase-3 was inhibited by the pan caspase inhibitor QVD.Oph. DNA alterations, including chromatin condensation and DNA degradation, were observed as a late step of cell death induction, as they are observed after $48 \mathrm{~h}$ of treatment, when most of the cells have undergone membrane permeability loss. We further showed that I-CRP induced ROS production in a caspase-independent manner, and that this production is indispensable for cell death induction.
The past decade has witnessed a steady accumulation of findings leading to the description of many cancer cell death pathways, opening the possibilities to eradicate apoptosis-resistant cells. These findings also suggest that multiple cell death modalities can engage common subcellular sites and organelles, and even share initiator and effector molecules [40, 41].

Caspase-independent cell death has been observed in a variety of cancer treatments, such as ionizing radiation [42], CD47 agonist peptides [13], berberine [43], differentiation inducing factor 3 [44], geranylated 4-phenylcoumarins [45], among others. Interestingly, this type of cell death could be used to prevent apoptosis resistance in tumor cells. In some cases, such as I-CRP, there is an activity of caspases but this activity is not necessary to carry out the cell death, this is because the caspases can be involved in non-lethal cell processes such as differentiation, normal cell signalling and maturation [46], in addition to their immune functions [47]. Like I-CRP other agents also induce activation of caspases but kill cancer cells through a caspase-independent mechanism, such it is the case of bisanthracycline WP 631 [48], selenosemicarbazone metal complexes [49], phenoxazine derivatives [50], among others. Many of these agents induce caspase-independent cell death mechanisms that have been well documented and whose characterization has helped to determine shared features of these types of cell death modalities, such is the case of matrine [51] and methylnitronitrosoguanidine (MNNG) $[52,53]$, that induce 


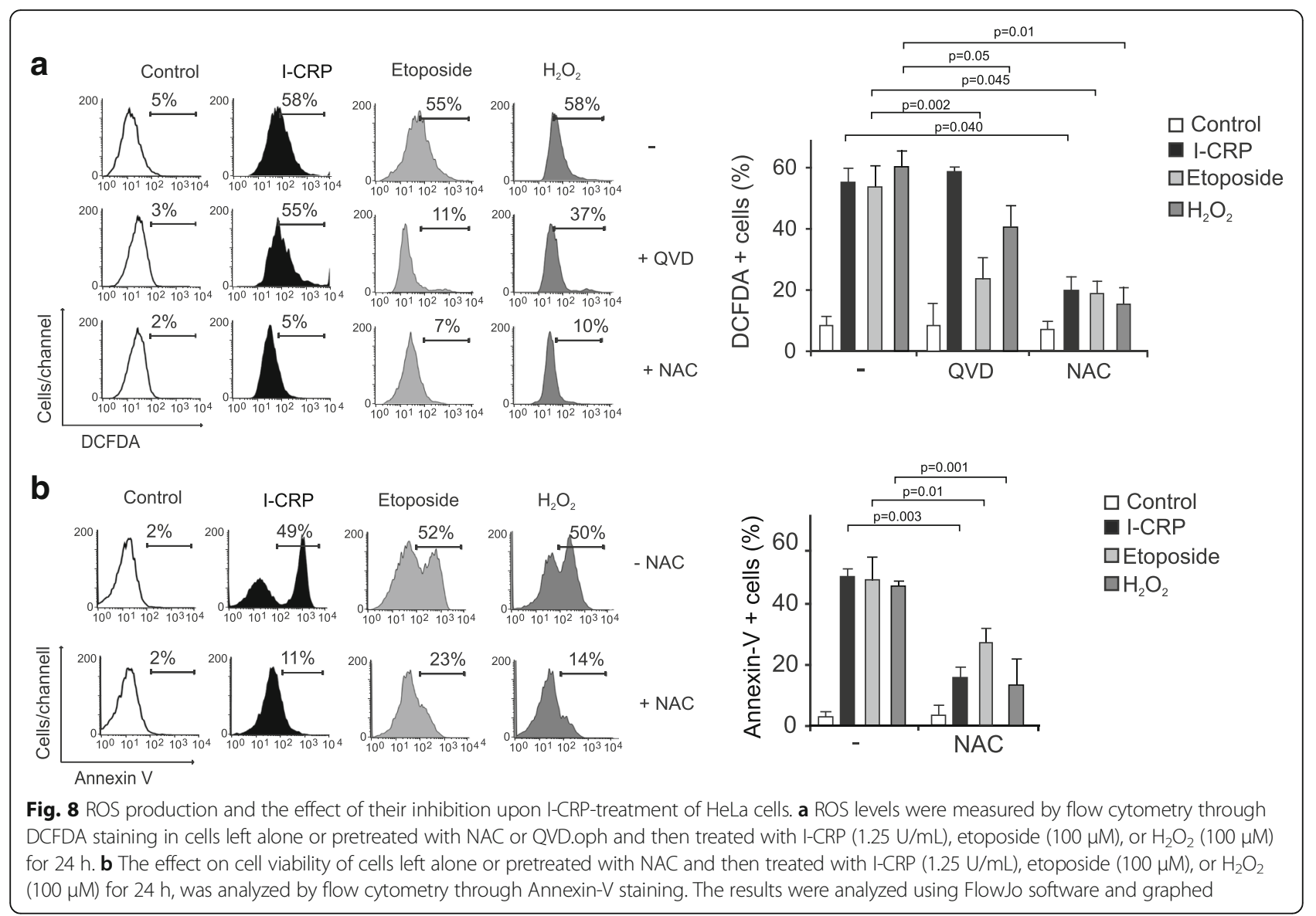

mitochondrial damage, and subsequently AIF-dependent cell death.

Cell cycle arrest in G1 phase [54-57], S phase [58], or G2/M phase $[59,60]$ has commonly been observed as an early step in several types of cell death [61-63]. Here we show that cell cycle was arrested in G2/M phase, and this was observed from $8 \mathrm{~h}$ to $48 \mathrm{~h}$ of treatment at a $1.25 \mathrm{U} / \mathrm{mL}$ concentration. There are several agents, such genistein [64], austrobailignan-1 [65], and curcumin analog WZ35 [66], that can also cause an arrest in the G2/M phase of the cell cycle followed by cell death induction. Although a recent publication of our research group showed that I-CRP does not affect cell cycle in bone marrow cells of mice treated with I-CRP [11], here we show that in cervical cancer cells it induces cell cycle arrest in G2/M phase, uncovering a different effect in cancer cells.

DNA degradation has become a crucial target for cell death induction, however, we should consider that blockage of DNA-degrading enzymes does not prevent cell death during apoptosis, and enucleated cytoplasts can be induced to undergo apoptosis [67], indicating that the nucleus is not always a prime target of apoptosis and cytoplasmic process can play a major role in the programmed cell death initiation. Here, we observed DNA alterations induced by
I-CRP, including partial chromatin condensation and DNA degradation as a late step of cell death induction (after $48 \mathrm{~h}$ of treatment) when most of the cells are dead, indicating that, DNA degradation does not play a role in this type of cell death, but it is a consequence of this process.

ROS are produced as a result of cellular metabolism at low-to-moderate concentrations and participate in physiological cell processes. However when produced at high concentrations, they produce adverse modifications to cell components, such as lipids, proteins, and DNA, affecting cellular organelles and functions and leading to cell death [68-72]. Caspase-independent cell death has been commonly associated with production of ROS [73, 74]. Some of these types of cell death can be associated with ROS, but independent of their production [75], or caspase-independent and ROS-dependent, such is the case of as Mn porphyrin in combination with ascorbate [76] and Obinutuzumab [77]. Yet, the cell death modalities that are ROS-dependent can be very vast and include autophagy, necrosis, pyroptosis, and mitoptosis $[23,70]$. As the cell death induced by I-CRP was ROS-dependent and the alterations in cell morphology seemed to include cytoplasmic vacuolization, autophagy could be an interesting clue to follow, to better characterize the cell death mechanism induced by I-CRP. 
Recently, our research group has published that I-CRP possess antioxidant capacity in lipopolysaccharide-stimulated human blood cells [78], murine peritoneal macrophages [79], and in bone marrow cells of 5-fluoracil-treated mice [11]. Here we show for the first time that I-CRP provokes ROS production in cancer cells, which are required for cell death induction. These results hint at a complex mechanism by which I-CRP induces a selective cell death depending on the type of cells. However, further studies are necessary to understand the differences of the cell mechanisms activated in different cell types.

The results shown here suggest that I-CRP can display multiple effects on cancer cells, yet ROS production was found to be indispensable for cell death. Many studies have involved ROS production in a variety of cell death modalities [23, 24, 69, 80, 81], and they can act as either initiators or executioners of cell death [24, 40,68]. Additional studies must be done to understand how ROS are produced after I-CRP treatment in HeLa cells and their role as initiators or executioner of cell death induced by I-CRP.

\section{Conclusions}

In conclusion, I-CRP treatment in HeLa cells diminishes cell viability through cell death and cell cycle arrest, which is accompanied by DNA alterations in the late steps of this type of RCD. Interestingly, caspase- 3 was modestly activated after I-CRP treatment, yet RCD was independent of caspase-activity. Furthermore, I-CRP treatment induces loss of mitochondrial membrane potential and ROS production. The use of the antioxidant NAC prevents ROS and cell death induced by I-CRP, indicating that I-CRP induces ROS-dependent cell death. Overall, this work sheds light into the regulated pathway by which I-CRP reduces cell viability in HeLa cells, uncovering a cell death modality that dispenses of caspase activation. This work opens the way to further analyze the characterization of this atypical type of cell death that might be activated in parallel with apoptosis-inducing chemotherapies.

\section{Additional files}

Additional file 1: Figure S1. (A) ROS levels were measured by flow cytometry through DCFDA staining in SiHa cells left alone or pretreated with NAC or QVD.oph and then treated with I-CRP $(1.25 \mathrm{U} / \mathrm{mL})$ for $24 \mathrm{~h}$. (B) The effect on cell death of cells left alone or pretreated with NAC or QVD.oph and then treated with I-CRP $(1.25 \mathrm{U} / \mathrm{mL})$ for $24 \mathrm{~h}$, was analyzed by flow cytometry through Annexin- $V$ staining. The results were analyzed and graphed. (PDF $20 \mathrm{~kb}$ )

Additional file 2: Figure S2. Left, caspase-3 activity of HeLa cells left untreated or pretreated with Nac, and then treated with I-CRP. Right, the results obtained were analyzed and graphed as the percentage of HeLa cells positive for caspase-3 activity. (PDF $37 \mathrm{~kb}$ )

\section{Abbreviations}

Ann/PI: Annexin-V-Allocp/ Propidium iodide.; I-CRP: Immunepotent-CRP. RCD: Regulated cell death

\section{Acknowledgements}

We thank Alejandra Arreola for article revision, Clara E. Isaza for preliminary data, William de J. Velazco, Karla Alvarez-Valadez and Alan B. Martinez-Loria for technical help, the Laboratorio de Inmunología y Virología from Facultad de Ciencias Biologicas of the Universidad Autonoma de Nuevo Leon for the funding and the facilities provided to achieve this work, the Red Tematica de Inmunologia en Cancer y Enfermedades Infecciosas of CONACYT for its collaboration, and to LONGEVEDEN S.A. de C.V. for the support provided to achieve this work

\section{Funding}

This work was supported by a research grant from the Proyecto de Apoyo a la Incorporación de Nuevos Profesores de Tiempo Completo (PROMEP DSA/103.5/14/ 10812) to AC Martinez-Torres and by the Laboratorio de Inmunología y Virología.

\section{Availability of data and materials}

All datasets generated during the current study are available from the corresponding author on reasonable request.

\section{Authors' contributions}

ACMT, ARR, MBL, MAFM, and CRP analyzed and interpreted data. ACMT, ARR, and MBL performed statistical analysis. ACMT conceived and designed the experiments, supervised work, and wrote the manuscript. ARR carried out the cell viability, cell cycle, cell death analysis, caspase, and ROS assessment. MBL carried out cell viability, and microscopy experiments. ARR, MBL, MAFM, and CRP helped to draft the manuscript. All authors read and approved the final manuscript.

Ethics approval and consent to participate Not applicable.

\section{Consent for publication}

Not applicable.

\section{Competing interests}

CRP and MAFM hold a patent for I-CRP. The rest of the authors declare that they have no competing interests.

\section{Publisher's Note}

Springer Nature remains neutral with regard to jurisdictional claims in published maps and institutional affiliations.

Received: 4 January 2017 Accepted: 21 December 2017

Published online: 03 January 2018

References

1. Siegel R, Ma J, Zou Z, Jemal A. Cancer statistics, 2014. CA Cancer J Clin. 2014:64:9-29.

2. Follen M, Levenback CF, lyer RB, Grigsby PW, Boss EA, Delpassand ES, et al. Imaging in cervical cancer. Cancer. 2003:98:2028-38.

3. Bell MC, Alvarez RD. Chemoprevention and vaccines: a review of the nonsurgical options for the treatment of cervical dysplasia. Int J Gynecol Cancer Blackwell Science Inc. 2005;15:4-12.

4. Hazra B, Ghosh S, Kumar A, Pandey BN. The prospective role of plant products in radiotherapy of cancer: a current overview. Front Pharmacol. 2011;2:94.

5. Ojeda MO, van't Veer C, Fernández Ortega CB, Araña Rosainz Mde J, Buurman WA. Dialyzable leukocyte extract differentially regulates the production of TNFalpha, IL-6, and IL-8 in bacterial component-activated leukocytes and endothelial cells. Inflamm Res. 2005:54:74-81.

6. Franco-Molina MA, Mendoza-Gamboa E, Miranda-Hernández D, ZapataBenavides P, Castillo-León L, Isaza-Brando C, et al. In vitro effects of bovine dialyzable leukocyte extract (bDLE) in cancer cells. Cytotherapy. 2006:8:408-14.

7. PEREZ-TAPIA SM, LOPEZ-ISLAS I, FUENTE-GRANADA MDLA, ARRATIAVALDELAMAR K, JIMENEZ-GALLEGOS N, RODRIGUEZ-FLORES A, et al. Use of dialyzable leukocyte extracts (DLE) in patients with severe sepsis (49.35). J Immunol. 2007;178:590.

8. Mendoza-Gamboa E, Franco-Molina MA, Zapata-Benavides P, Castillo-Tello P, Vera-García ME, Tamez-Guerra RS, et al. Bovine dialyzable leukocyte extract modulates AP-1 DNA-binding activity and nuclear transcription factor expression in MCF-7 breast cancer cells. Cytotherapy. 2008;10:212-9. 
9. Lara HH, Ixtepan-Turrent L, Garza-Treviño EN, Tamez-Guerra R, Rodriguez-Padilla C. Clinical and immunological assessment in breast cancer patients receiving anticancer therapy and bovine dialyzable leukocyte extract as an adjuvant. Exp Ther Med Spandidos Publications. 2010;1:425-31.

10. Franco-Molina MA, Mendoza-Gamboa E, Zapata-Benavides $P$ Castillo-Tello P, Isaza-Brando CE, Zamora-Avila D, et al. Antiangiogenic and antitumor effects of IMMUNEPOTENT CRP in murine melanoma. Immunopharmacol Immunotoxicol. 2010;32:637-46.

11. Coronado-Cerda EE, Franco-Molina MA, Mendoza-Gamboa E, Prado-García H, Rivera-Morales LG, Zapata-Benavides P, et al. In Vivo Chemoprotective activity of bovine dialyzable leukocyte extract in mouse bone marrow cells against damage induced by 5-fluorouracil. J Immunol Res Hindawi Publishing Corporation. 2016;2016:1-10.

12. Arnaudov A, Kostova Z. Dialysable leukocyte extracts in immunotherapy. Med. Biotechnol: Taylor \& Francis; 2015.

13. Martinez-Torres A-C, Quiney C, Attout T, Boullet H, Herbi L, Vela L, et al. CD47 agonist peptides induce programmed cell death in refractory chronic lymphocytic leukemia B cells via PLCY1 activation: evidence from mice and humans. PLoS Med. 2015;12:e1001796.

14. Liu Y, Dai H, Xiao W. UAS(MAG1), a yeast cis-acting element that regulates the expression of MAG1, is located within the protein coding region of DDI1. Mol Gen Genet. 1997;255:533-42.

15. Kroemer G, Galluzzi L, Vandenabeele P, Abrams J, Alnemri ES, Baehrecke EH, et al. Classification of cell death: recommendations of the nomenclature committee on cell death 2009. Cell Death Differ. 2009;16:3-11.

16. Thomadaki H, Tsiapalis CM, Scorilas A. Polyadenylate polymerase modulations in human epithelioid cervix and breast cancer cell lines, treated with etoposide or cordycepin, follow cell cycle rather than apoptosis induction. Biol Chem. 2005;386(5):471-80.

17. Leist $M$, Jäättelä M. Four deaths and a funeral: from caspases to alternative mechanisms. Nat Rev Mol Cell Biol Nature Publishing Group. 2001;2:589-98.

18. Toné S, Sugimoto K, Tanda K, Suda T, Uehira K, Kanouchi H, et al. Three distinct stages of apoptotic nuclear condensation revealed by time-lapse imaging, biochemical and electron microscopy analysis of cell-free apoptosis. Exp Cell Res. 2007;313:3635-44.

19. Caserta TM, Smith AN, Gultice AD, Reedy MA, Brown TL. Q-VD-OPh, a broad spectrum caspase inhibitor with potent antiapoptotic properties. Apoptosis. 2003:8:345-52

20. Vakifahmetoglu-Norberg H, Ouchida AT, Norberg E. The role of mitochondria in metabolism and cell death. Biochem Biophys Res Commun. 2017;482(3):426-31

21. Suski JM, Lebiedzinska M, Bonora M, Pinton P, Duszynski J, Wieckowski MR Relation between mitochondrial membrane potential and ROS formation. Methods Mol Biol. 2012;810:183-205.

22. Murphy MP. Mitochondrial dysfunction indirectly elevates ROS production by the endoplasmic reticulum. Cell Metab. 2013;18:145-6.

23. Panieri E, Gogvadze V, Norberg E, Venkatesh R, Orrenius S, Zhivotovsky B. Reactive oxygen species generated in different compartments induce cell death, survival, or senescence. Free Radic Biol Med. 2013;57:176-87.

24. Poillet-Perez L, Despouy G, Delage-Mourroux R, Boyer-Guittaut M. Interplay between ROS and autophagy in cancer cells, from tumor initiation to cancer therapy. Redox Biol. 2015;4:184-92.

25. Zafarullah M, Li WQ, Sylvester J, Ahmad M. Molecular mechanisms of Nacetylcysteine actions. Cell Mol Life Sci. 2003;60:6-20.

26. Sun S.-Y. N-acetylcysteine, reactive oxygen species and beyond. Cancer Biol Ther. 2010;9(2):109-10.

27. IARC. World Cancer Report 2014. 2014.

28. Torre LA, Bray F, Siegel RL, Ferlay J, Lortet-Tieulent J, Jemal A. Global cancer statistics, 2012. CA Cancer J Clin. 2015;65:87-108.

29. Klemm F, Joyce JA. Microenvironmental regulation of therapeutic response in cancer. Trends Cell Biol. 2015:25:198-213.

30. Formenti SC, Demaria S. Combining radiotherapy and cancer immunotherapy: a paradigm shift. J Natl Cancer Inst Oxford University Press. 2013;105:256-65.

31. James ND, Hussain SA, Hall E, Jenkins P, Tremlett J, Rawlings C, et al. Radiotherapy with or without chemotherapy in muscle-invasive bladder cancer. N Engl J Med. 2012;366:1477-88.

32. Fudenberg HH. DIALYZABLE TRANSFER FACTOR IN THE TREATMENT OF HUMAN OSTEOSARCOMA: AN ANALYTIC REVIEW. Ann. N. Y. Acad. Sci. Blackwell Publishing Ltd. 1976;277:545-57.
33. Pizza G, De Vinci C, Cuzzocrea D, Menniti D, Aiello E, Maver P, et al. A preliminary report on the use of transfer factor for treating stage D3 hormone-unresponsive metastatic prostate cancer. Biotherapy Kluwer Academic Publishers. 1996:9:123-32.

34. Pilotti V, Mastrorilli M, Pizza G, De Vinci C, Busutti L, Palareti A, et al. Transfer factor as an adjuvant to non-small cell lung cancer (NSCLC) therapy. Biotherapy Kluwer Academic Publishers. 1996;9:117-21.

35. Franco-Molina MA, Mendoza-Gamboa E, Zapata-Benavides P, Vera-Garcia M. E. Castillo-Tello P, de la Fuente AG, Rodríguez-Padilla C. IMMUNEPOTENT CRP (bovine dialyzable leukocyte extract) adjuvant immunotherapy: a phase I study in non-small cell lung cancer patients. Cytotherapy. 2008;10:490-6.

36. Krishnaveni M. A review on transfer factor an immune modulator. Drug Invent Today. 2013;5:153-6.

37. Hamprecht KH, Vötsch W, Anderer FA. A Dialysable acid factor from human leukocyte extracts activates tumor cell Lysis mediated by human Monocytes and natural killer cells. Oncol Res Treat Karger Publishers. 2009;12:120-7.

38. Spitler LE, Levin AS, Wybran J. Combined immunotherapy in malignant melanoma. Cell Immunol Academic Press. 1976;21:1-19.

39. Láng I, Nékám K, Gergely P, Petrányi G. Effect of in vivo and in vitro treatment with dialyzable leukocyte extracts on human natural killer cell activity. Clin Immunol Immunopathol Academic Press. 1982;25:139-44.

40. Nikoletopoulou V, Markaki M, Palikaras K, Tavernarakis N. Crosstalk between apoptosis, necrosis and autophagy. Biochim Biophys Acta - Mol Cell Res. 1833;2013:3448-59.

41. Galluzzi L, Bravo-San Pedro JM, Vitale I, Aaronson SA, Abrams JM, Adam D, et al. Essential versus accessory aspects of cell death: recommendations of the NCCD 2015. Cell Death Differ Macmillan Publishers Limited. 2014;22:58-73.

42. Sun H, Yang S, Li J, Zhang Y, Gao D, Zhao S. Caspase-independent cell death mediated by apoptosis-inducing factor (AIF) nuclear translocation is involved in ionizing radiation induced HepG2 cell death. Biochem Biophys Res Commun. 2016;472(1):137-43.

43. Wang L, Liu L, Shi Y, Cao H, Chaturvedi R, Calcutt MW, et al. Berberine induces Caspase-independent cell death in colon tumor cells through activation of apoptosis-inducing factor. PLoS One. 2012;7:e36418. Linden R, editor. Public Library of Science

44. Dubois A, Ginet C, Furstoss N, Belaid A, Hamouda MA, El Manaa W, et al. Differentiation inducing factor 3 mediates its anti-leukemic effect through ROS-dependent DRP1-mediated mitochondrial fission and induction of caspase-independent cell death. Oncotarget. 2016;7(18):26120-36.

45. Suparii NS, Chan G, Sapili H, Arshad NM, In LLA, Awang K, et al. Geranylated 4-Phenylcoumarins exhibit anticancer effects against human prostate cancer cells through Caspase-independent mechanism. PLoS One. 2016;11: e0151472. Ulasov I, editor. Public Library of Science

46. McLaughlin B. The kinder side of killer proteases: Caspase activation contributes to neuroprotection and CNS remodeling. Apoptosis Kluwer Academic Publishers. 2004;9:111-21.

47. Abraham MC, Shaham S. Death without caspases, caspases without death. Trends Cell Biol. 2004;14:184-93.

48. Gajek A, Denel M, Bukowska B, Rogalska A, Marczak A. Pro-apoptotic activity of new analog of anthracyclines - WP 631 in advanced ovarian cancer cell line. Toxicol Vitr. 2014;28:273-81.

49. Zec M, Srdic-Rajic T, Krivokuca A, Jankovic R, Todorovic T, Andelkovic K, et al. Novel Selenosemicarbazone metal complexes exert anti-tumor effect via alternative, Caspase-independent necroptotic cell death. Med Chem. 2014:10(8):759-71.

50. Shirato K, Imaizumi K, Abe A, Tomoda A. Phenoxazine derivatives 2-Amino4,4a-dihydro-4a-phenoxazine-3-one and 2-Aminophenoxazine-3-oneinduced apoptosis through a Caspase-independent mechanism in human Neuroblastoma cell line NB-1 cells. Biol Pharm Bull. 2007;30:331-6.

51. Zhou H, Xu M, Gao Y, Deng Z, Cao H, Zhang W, et al. Matrine induces caspase-independent program cell death in hepatocellular carcinoma through bid-mediated nuclear translocation of apoptosis inducing factor. Mol Cancer. 2014;13:59.

52. Cabon L, Galán-Malo P, Bouharrour A, Delavallée L, Brunelle-Navas M-N, Lorenzo HK, et al. BID regulates AIF-mediated caspase-independent necroptosis by promoting BAX activation. Cell Death Differ. 2012;19:245-56.

53. Dric Artus C, Boujrad H, Bouharrour A, Lle Brunelle M-N, Hoos S, Yuste VJ, et al. AlF promotes chromatinolysis and caspase- independent programmed necrosis by interacting with histone H2AX. EMBO J. 2010;2943:1585-99.

54. Yano H, Mizoguchi A, Fukuda K, Haramaki M, Ogasawara S, Momosaki S, et al. The herbal medicine sho-saiko-to inhibits proliferation of cancer cell 
lines by inducing apoptosis and arrest at the G0/G1 phase. Cancer Res American Association for Cancer Research. 1994;54:448-54.

55. Mantena SK, Sharma SD, Katiyar SK. Berberine, a natural product, induces G1-phase cell cycle arrest and caspase-3-dependent apoptosis in human prostate carcinoma cells. Mol Cancer Ther Molecular Cancer Therapeutics. 2006:5:296-308.

56. Bröker LE, Kruyt FAE, Giaccone G. Cell death independent of caspases: a review. Clin Cancer Res. 2005;11:3155-62.

57. Ahmad N, Adhami VM, Afaq F, Feyes DK, Mukhtar H. Resveratrol causes WAF-1/p21-mediated G(1)-phase arrest of cell cycle and induction of apoptosis in human epidermoid carcinoma A431 cells. Clin Cancer Res. 2001;7:1466-73.

58. van Rijt SH, Romero-Canelón I, Fu Y, Shnyder SD, Sadler PJ. Potent organometallic osmium compounds induce mitochondria-mediated apoptosis and S-phase cell cycle arrest in A549 non-small cell lung cancer cells. Metallomics. 2014;6:1014.

59. Pal HC, Sharma S, Elmets CA, Athar M, Afaq F. Fisetin inhibits growth, induces $G_{2} / M$ arrest and apoptosis of human epidermoid carcinoma A431 cells: role of mitochondrial membrane potential disruption and consequent caspases activation. Exp Dermatol. 2013;22:470-5.

60. Bishayee K, Ghosh S, Mukherjee A, Sadhukhan R, Mondal J, Khuda-Bukhsh AR. Quercetin induces cytochrome-c release and ROS accumulation to promote apoptosis and arrest the cell cycle in G2/M, in cervical carcinoma: signal cascade and drug-DNA interaction. Cell Prolif. 2013;46:153-63.

61. Hartwell LH, Kastan MB. Cell cycle control and cancer. Science (80- ). 1994;266:1821.

62. Waldman T, Zhang Y, Dillehay L, Yu J, Kinzler K, Vogelstein B, et al. Cell-cycle arrest versus cell death in cancer therapy. Nat Med. 1997;3:1034-6.

63. Kastan MB, Bartek J. Cell-cycle checkpoints and cancer. Nature Nature Publishing Group. 2004;432:316-23.

64. Zhang Z, Wang C-Z, Du G-J, Qi L-W, Calway T, He T-C, et al. Genistein induces G2/M cell cycle arrest and apoptosis via ATM/p53-dependent pathway in human colon cancer cells. Int J Oncol Spandidos Publications. 2013;43:289-96.

65. Wu C-C, Huang K-F, Yang T-Y, Li Y-L, Wen C-L, Hsu S-L, et al. The Topoisomerase 1 inhibitor Austrobailignan-1 isolated from Koelreuteria Henryi induces a G2/M-phase arrest and cell death independently of p53 in non-small cell lung cancer cells. PLoS One. 2015;10:e0132052. Fei P, editor. Public Library of Science

66. Zhang X, Chen M, Zou P, Kanchana K, Weng Q, Chen W, et al. Curcumin analog WZ35 induced cell death via ROS-dependent ER stress and G2/M cell cycle arrest in human prostate cancer cells. BMC Cancer. 2015;15:866.

67. Nakajima H, Golstein P, Henkart PA. The target cell nucleus is not required for cell-mediated granzyme- or Fas-based cytotoxicity. J Exp Med. 1995;181:1905-9.

68. Birben E, Sahiner UM, Sackesen C, Erzurum S, Kalayci O, Valko M, et al. Oxidative stress and antioxidant defense. World Allergy Organ J BioMed Central. 2012;5:9-19.

69. Dixon SJ, Stockwell BR. The role of iron and reactive oxygen species in cell death. Nat Chem Biol Nature Research. 2013;10:9-17.

70. Jacobson MD. Reactive oxygen species and programmed cell death. Trends Biochem Sci Elsevier Current Trends. 1996;21:83-6.

71. Rodríguez-Serrano M, Bárány I, Prem D, Coronado M-J, Risueño MC, Testillano PS. NO, ROS, and cell death associated with caspase-like activity increase in stress-induced microspore embryogenesis of barley. J Exp Bot Oxford University Press. 2012;63:2007-24.

72. Nathan C, Cunningham-Bussel A. Beyond oxidative stress: an immunologist's guide to reactive oxygen species. Nat Rev Immunol Nature Publishing Group. 2013;13:349-61.

73. Tait SWG, Green DR. Cut. 2009;27:6452-61.

74. Kang Y-H, Yi M-J, Kim M-J, Park M-T, Bae S, Kang C-M, et al. Caspaseindependent cell death by arsenic trioxide in human cervical cancer cells: reactive oxygen species-mediated poly(ADP-ribose) polymerase-1 activation signals apoptosis-inducing factor release from mitochondria. Cancer Res. 2004:64:8960-7.

75. Perdomo J, Cabrera J, Estévez F, Loro J, Reiter RJ, Quintana J. Melatonin induces apoptosis through a caspase-dependent but reactive oxygen species-independent mechanism in human leukemia Molt-3 cells. J Pineal Res. 2013:55:195-206.

76. Evans MK, Tovmasyan A, Batinic-Haberle I, Devi GR. Mn porphyrin in combination with ascorbate acts as a pro-oxidant and mediates caspaseindependent cancer cell death. Free Radic Biol Med. 2014;68:302-14.
77. Honeychurch J, Alduaij W, Azizyan M, Cheadle EJ, Pelicano H, Ivanov A, et al Antibody-induced nonapoptotic cell death in human lymphoma and leukemia cells is mediated through a novel reactive oxygen speciesdependent pathway. Blood. 2012;119(15):3523-33.

78. Franco-Molina M, Mendoza-Gamboa E, Castillo-Tello P, Isaza-Brando C, García MV, Castillo-León L, et al. Bovine dialyzable leukocyte extract modulates cytokines and nitric oxide production in lipopolysaccharidestimulated human blood cells. Cytotherapy. 2007;9(4):379-85.

79. Franco-Molina MA, Mendoza-Gamboa E, Castillo-León L, Tamez-Guerra RS, Rodríguez-Padilla C. Bovine dialyzable leukocyte extract modulates the nitric oxide and pro-inflammatory cytokine production in Lipopolysaccharidestimulated Murine peritoneal macrophages in vitro. 2 Madison Avenue Larchmont, NY 10538 USA: Mary Ann Liebert, Inc; 2005.

80. Festjens N, Vanden Berghe T, Vandenabeele P. Necrosis, a well-orchestrated form of cell demise: signalling cascades, important mediators and concomitant immune response. Biochim Biophys Acta. 2006;1757:1371-87.

81. Yuzefovych LV, LeDoux SP, Wilson GL, Rachek LI. Mitochondrial DNA damage via augmented oxidative stress regulates endoplasmic reticulum stress and autophagy: crosstalk, links and signaling. PLoS One. 2013:8:e83349.

\section{Submit your next manuscript to BioMed Central and we will help you at every step:}

- We accept pre-submission inquiries

- Our selector tool helps you to find the most relevant journal

- We provide round the clock customer support

- Convenient online submission

- Thorough peer review

- Inclusion in PubMed and all major indexing services

- Maximum visibility for your research

Submit your manuscript at www.biomedcentral.com/submit
C Biomed Central 